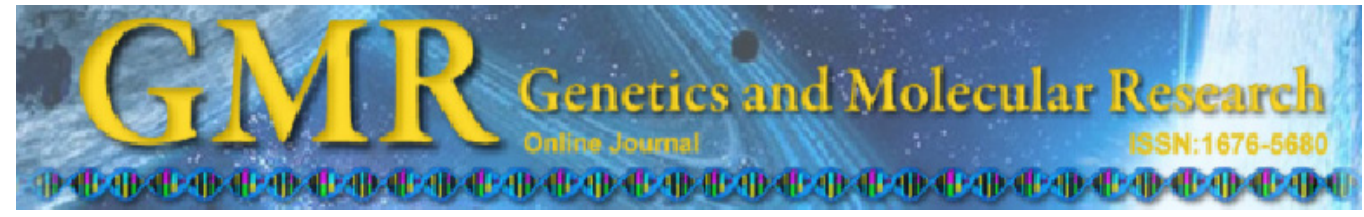

\title{
Prolactin-releasing peptide mRNA expression in mouse medulla remains relatively stable during pregnancy and lactation
}

\author{
H.S. Zhu, J.X. Du, Y.Y. Wang, L.F. Wang, L.Q. Hang, G.Y. Yang \\ and Y.L. Wang \\ Key Laboratory of Regulation on Animal Growth and Development, \\ Agricultural Ministry of China, Henan Agricultural University, \\ Zhengzhou, P.R. China \\ Corresponding author: H.S. Zhu \\ E-mail: zhuheshui@163.com
}

Genet. Mol. Res. 10 (2): 615-620 (2011)

Received November 24, 2010

Accepted February 1, 2011

Published April 12, 2011

DOI 10.4238/vol10-2gmr1086

\begin{abstract}
We compared levels of prolactin-releasing peptide (PrRP) mRNA expression in mouse medulla at different stages of pregnancy and lactation. Mouse medulla samples were collected on days 6, 12 and 18 of pregnancy and lactation, respectively (six per group), for mRNA. Expression levels of PrRP mRNA in the medulla were measured by semi-quantitative RT-PCR, with glyceraldehyde 3-phosphate dehydrogenase as a control. PrRP mRNA was highly expressed in mouse medulla oblongata on day 6 of pregnancy $(0.53)$, followed by 0.43 at lactation day 6 , and 0.42 at lactation day 12 . The expression level of PrRP mRNA on days 12 and 18 of pregnancy and day 18 of lactation shared the same value of 0.36. PrRP mRNA levels during lactation decreased slightly compared with that during pregnancy, but the differences between them were not significant. In summary, PrRP mRNA levels in the medulla oblongata remain relatively stable during pregnancy and lactation. This is evidence that medulla PrRP is not involved in the regulation of prolactin secretion.
\end{abstract}

Key words: PrRP; Mouse; Pregnancy; Lactation 


\section{INTRODUCTION}

Most anterior pituitary hormone secretion is regulated by hypothalamic peptide hormones in a specific manner through the portal vein; however, the hypothalamic peptides specifically regulating the secretion of prolactin remain unknown. In 1998, a hypothalamic peptide was found as a ligand of an orphan seven-transmembrane-domain receptor in pituitary by reverse pharmacological approach and named prolactin-releasing peptide (PrRP) as it is a stimulator of prolactin release from the anterior pituitary (Hinuma et al., 1998). Except for the hypothalamus, PrRP mRNA is abundantly expressed in the medulla oblongata and in fibers containing PrRP, which are widely distributed in the brain (Maruyama et al., 1999; Yamakawa et al., 1999; Ibata et al., 2000; Yamada et al., 2001). So PrRP may act as a neurotransmitter as well as a peptide hormone regulating prolactin. We performed a molecular biology study to clarify the PrRP developmental expression changes in the mouse medulla during pregnancy and lactation for further evidence to elucidate the physiological role of PrRP.

\section{MATERIAL AND METHODS}

\section{Animals and treatment}

Young mice, aged approximately 2 weeks, were obtained from the Centre for Laboratory Animal of Henan Province. Animals were maintained in group cages under controlled conditions of temperature $\left(25 \pm 1^{\circ} \mathrm{C}\right)$ and a 12-h light-dark cycle, with ad libitum access to food and water. The stage of the estrous cycle was monitored by collection of daily vaginal smears and those showing at least 2 consecutive estrous cycles were used. Groups of proestrous mice were paired with males by the ratio $2: 1$ and mating was confirmed by the presence of sperm in the vaginal smear the following day. Pregnant animals were monitored daily to define day of lactation. All procedures were approved by the Animal Ethics Committee.

Groups of mice (6 per group) on days 6,12 and 18 of pregnancy $(\mathrm{P})$ and lactation (L) were killed at 9:00 h by decapitation, respectively. Medulla oblongata were rapidly removed and immediately frozen with liquid nitrogen.

\section{RNA extraction and reverse transcriptase}

Total RNA were extracted with RNA out extract and stored at $-80^{\circ} \mathrm{C}$. The concentration of RNA was estimated by spectrophotometry using UV absorbance at 260 and $280 \mathrm{~nm}$. The integrity of RNA was determined by denaturing agarose gel electrophoresis. Total RNA was extracted following conventional protocol and dissolved with $20 \mu \mathrm{L}$ RNase-free water.

The RNA was reverse transcribed with a reaction mix containing DEPC- $\mathrm{H}_{2} \mathrm{O}(6.5 \mu \mathrm{L}) 5 \mathrm{X}$ buffer $(4 \mu \mathrm{L}), 2.5 \mathrm{mM}$ dNTP mix (4 $\mu \mathrm{L}), 50 \mathrm{pM}$ Oligo (dT) $18(1 \mu \mathrm{L}), 5 \mu / \mu \mathrm{L}$ AMV $(2 \mu \mathrm{L}), 40 \mu /$ $\mu \mathrm{L}$ RNase inhibitor $(0.5 \mu \mathrm{L})$ and RNA $(2 \mu \mathrm{L})$. The total reaction volume was $20 \mu \mathrm{L}$. After gently mixed, the solution was incubated for $60 \mathrm{~min}$ at $42^{\circ} \mathrm{C}$, then for $15 \mathrm{~min}$ at $72^{\circ} \mathrm{C}$, followed by an ice bath for $2 \mathrm{~min}$. Two controls were done in the reverse transcriptase (RT) reaction, one control was prepared using all reagents except the RNA sample, for which an equivalent volume of water was substituted, and the other control was prepared using all reagents except the reverse transcriptase. The controls underwent identical polymerase chain reaction (PCR) procedures to experimental samples. 


\section{RT-PCR}

The obtained cDNAs were further amplified by PCR in $25 \mu \mathrm{L}$ total volume mix, which consists of RT reaction solution $(1 \mu \mathrm{L}), 2 \mathrm{X}$ Master mix $(12.5 \mu \mathrm{L}), 20 \mathrm{pM}$ forward primer $(1$ $\mu \mathrm{L}), 20 \mathrm{pM}$ reverse primer $(1 \mu \mathrm{L})$ and sterilized $\mathrm{H}_{2} \mathrm{O}(9.5 \mu \mathrm{L})$. The reaction substrates were mixed by gently flicking the bottom of each tube. PCR amplification was carried out for $30 \mathrm{cy}-$ cles $\left(94^{\circ} \mathrm{C}, 20 \mathrm{~s} ; 62^{\circ} \mathrm{C}, 20 \mathrm{~s} ; 72^{\circ} \mathrm{C}, 20 \mathrm{~s}\right)$ for $\operatorname{PrRP}$ and 30 cycles $\left(94^{\circ} \mathrm{C}, 20 \mathrm{~s} ; 57^{\circ} \mathrm{C}, 20 \mathrm{~s} ; 72^{\circ} \mathrm{C}\right.$, $20 \mathrm{~s})$ for GAPDH. Samples were finished with the final extension at $72^{\circ} \mathrm{C}$ for $5 \mathrm{~min}$. Every $5-\mu \mathrm{L}$ sample PCR amplification product was mixed gently with $3 \mu \mathrm{L}$ fluorochrome before protection from light for $10 \mathrm{~min}$, then viewed on 1.5\% agarose gel with a Multi-Image Light system.

\section{Statistical treatment of results}

All results are reported as means $\pm \mathrm{SD}$ and analyzed by the Statistical Package for the Social Sciences (SPSS) statistical software (version 13.0). Differences among group data were compared using the Student-Newman-Keuls post hoc test of one-way analysis of variance (ANOVA), and differences between groups were compared using the paired-samples $t$-test. Significance was set at $\mathrm{P}<0.05$ and $\mathrm{P}<0.01$ in two-tailed testing.

\section{RESULTS}

Gel electrophoresis showing RT-PCR of PrRP in medulla oblongata indicated that a single PCR product of about $161 \mathrm{bp}$ was obtained in all samples (Figure 1). The relative expression level of PrRP mRNA in medulla oblongata of mice during pregnancy and lactation is shown in Table 1 and Figure 2.

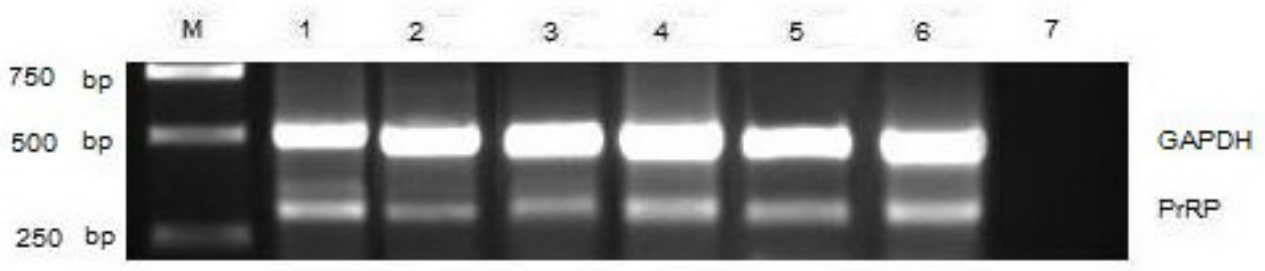

Figure 1. Gel electrophoresis of RT-PCR products in medulla. Lane $M=$ Molecular marker; lane 1 = P6; lane 2 = $\mathrm{P} 12$; lane $3=\mathrm{P} 18$; lane $4=\mathrm{L} 6$; lane $5=\mathrm{L} 12 ;$ lane $6=\mathrm{L} 18 ;$ lane $7=$ control.

Table 1. Relative expression level of PrRP mRNA to GAPDH in medulla during pregnancy and lactation.

\begin{tabular}{lcc}
\hline Groups & Sample numbers & PrRP/GAPDH \\
\hline P6 & 6 & $0.53 \pm 0.10$ \\
P12 & 6 & $0.36 \pm 0.14$ \\
P18 & 6 & $0.36 \pm 0.12$ \\
L6 & 6 & $0.43 \pm 0.21$ \\
L12 & 6 & $0.42 \pm 0.26$ \\
L18 & 6 & $0.36 \pm 0.18$ \\
\hline
\end{tabular}

$\mathrm{P}=$ pregnancy; $\mathrm{L}=$ lactation. 


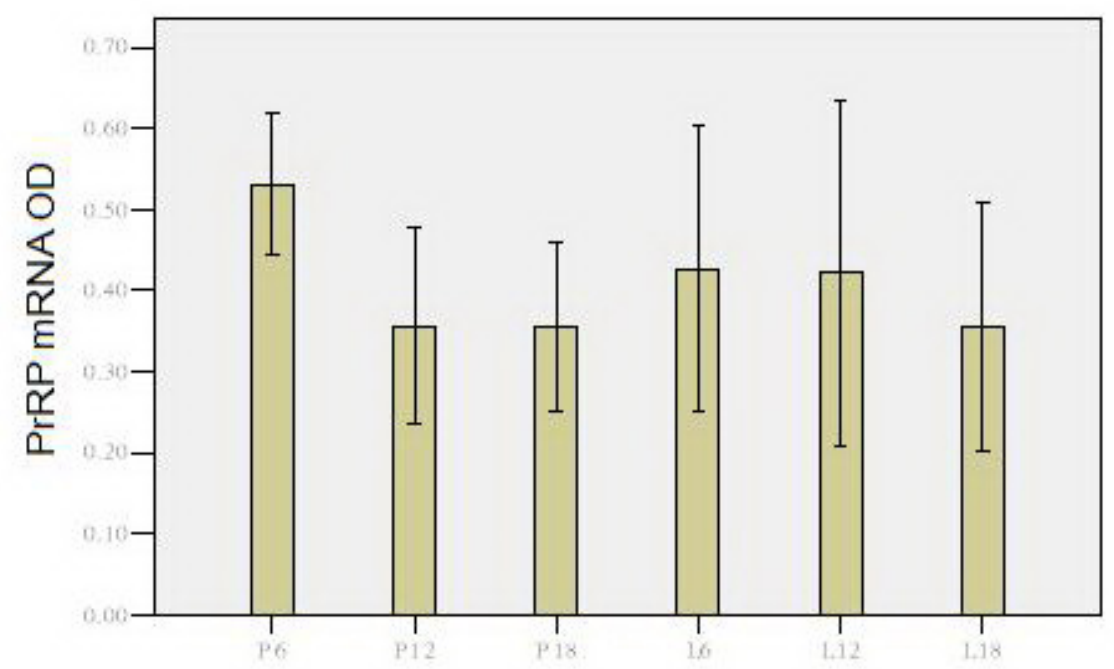

Figure 2. Relative expression level of PrRP mRNA to GAPDH in medulla during pregnancy (P) and lactation (L).

As shown in Table 1 and Figure 2, during pregnancy and lactation, PrRP mRNA in medulla oblongata maintains a relatively stable level $(\mathrm{P}>0.05)$. PrRP mRNA was highly expressed in mouse medulla oblongata on P6 (0.53), followed by 0.43 on L6, and 0.42 on L12. The expression level of PrRP mRNA on P12, P18 and L18 was the same, 0.36. PrRP mRNA during lactation decreased slightly compared with that during pregnancy, but the difference between them was insignificant $(\mathrm{P}>0.05)$.

\section{DISCUSSION}

During developmental stages of rat fetuses and neonates, PrRP mRNA was first expressed in medulla but not hypothalamus. The PrRP mRNA was expressed in the nucleus of the solitary tract (NTS) at embryonic day 18 (E18) and in the ventral and lateral reticular nucleus (VLRN) of the caudal medulla oblongata at E20. PrRP mRNA in the hypothalamus was first expressed at postnatal day 13 (Yano et al., 2001).

From embryonal day 14 to postnatal day 0 during the embryonal expression, PrRP gene expression was seen in the caudal solitary tract nucleus, medullary reticular formation, pontine isthmus and liver, kidney and testis. And PrRP genes showed weak but even in situ hybridization (ISH) signal in the pituitary (Nieminen et al., 2003).

At different stages of the estrous cycle, the nucleus of the NTS and VLRN of the medulla oblongata contained significantly $(\mathrm{P}<0.05)$ greater levels of PrRP mRNA than any hypothalamic region. Within the hypothalamus, the highest level of PrRP expression was located on the dorsomedial aspect of the ventromedial hypothalamus. All other hypothalamic regions exhibited significantly $(\mathrm{P}<0.05)$ lower levels of expression, including the rostral and caudal dorsomedial hypothalamus. Very low levels of PrRP expression were observed in the arcuate nucleus, paraventricular nucleus, medial preoptic nucleus, and ventrolateral aspect of the ventromedial hypothalamus. No significant changes in PrRP expression were noted in 
any sampled region between proestrus, estrus or diestrus (Anderson et al., 2003). But other research showed that there were fewer PrRP immunoreactive neurons in the NTS and VLRN in proestrus than in diestrus, estrus or metaestrus. Similarly, the relative optical density of PrRP-ir fibers of the bed nucleus of stria terminalis (BST) in proestrus decreased compared with those in the other three groups. However, the brain PrRP mRNA level was higher in proestrus and estrus than in metaestrus and diestrus (Feng et al., 2007). The latter results provide morphological evidence that PrRP in the female rat brains might participate in the regulation of the rat estrous cycle in an indirect way.

The distribution of PrRP mRNA signals in the medulla of rat on day 7 of pregnancy was very similar to those of adult males. In the medulla oblongata, two discrete areas contained PrRP mRNA signals. No positive signal was found in the rostral part of the medulla oblongata extending to the anterior part of the area postrema. The caudal part of the NTS had neurons with very strong signals of PrRP mRNA. The reticular nucleus showed a few PrRP mRNA-positive neurons (Lee et al., 2000).

As the pregnancy progressed PrRP mRNA content in the NTS increased and peaked on the 14th day, the mid-period of pregnancy, when plasma progesterone increases. These findings indicate that PrRP gene expression is regulated by gonadal steroid hormones in the medulla oblongata, and parts of PrRP synthesizing neurons are considered to be directly influenced by estrogen in the NTS (Kataoka et al., 2001).

With regard to both male and diestrous female controls, the PrRP mRNA signal was reduced in the medulla of lactating dams, with cell counts revealing 42 and $43 \%$ reductions in the number of positively hybridized cells in the NTS and ventrolateral medulla, respectively. Acute exposure to hypotensive hemorrhage or footshock activated substantial complements of medullary neurons expressing PrRP mRNA. A substantially greater fraction of the total medullary PrRP population exhibited sensitivity to footshock than hemorrhage. The results suggest that medullary PrRP neurons are negatively regulated by changes in lactation, and are not recruited to activation by suckling stimuli (Morales and Sawchenko, 2003). Lawrence et al. (2000) reported that the expression of PrRP mRNA reduced during lactation and fasting, so PrRP may have an acute effect on food intake and body weight. As the present study showed, medullary PrRP mRNA expressed at a steady level during pregnancy and lactation, although the average PrRP mRNA level during pregnancy was slightly higher than that during lactation $(\mathrm{P}>0.05)$. In another study, we found mouse PrRP gene expression also in the hypothalamus, pituitary, adrenal gland, ovary, and thyroid gland with lower levels compared to the medulla. The results indicated that medulla PrRP may play an important role in regulating some physiological action other than modulating PRL during pregnancy and lactation.

\section{ACKNOWLEDGMENTS}

Research supported by the Project of National 11th Five-Year Plan Scientific and Technological Issues (\#2006BAD04A03-10).

\section{REFERENCES}

Anderson ST, Kokay IC, Lang T, Grattan DR, et al. (2003). Quantification of prolactin-releasing peptide (PrRP) mRNA expression in specific brain regions of the rat during the oestrous cycle and in lactation. Brain Res. 973: 64-73.

Feng Y, Zhao H, An XF, Ma SL, et al. (2007). Expression of brain prolactin releasing peptide (PrRP) changes in the 
estrous cycle of female rats. Neurosci. Lett. 419: 38-42.

Hinuma S, Habata Y, Fujii R, Kawamata Y, et al. (1998). A prolactin-releasing peptide in the brain. Nature 393: 272-276.

Ibata Y, Iijima N, Kataoka Y, Kakihara K, et al. (2000). Morphological survey of prolactin-releasing peptide and its receptor with special reference to their functional roles in the brain. Neurosci. Res. 38: 223-230.

Kataoka Y, Iijima N, Yano T, Kakihara K, et al. (2001). Gonadal regulation of PrRP mRNA expression in the nucleus tractus solitarius and ventral and lateral reticular nuclei of the rat. Brain Res. Mol. Brain Res. 87: 42-47.

Lawrence CB, Celsi F, Brennand J and Luckman SM (2000). Alternative role for prolactin-releasing peptide in the regulation of food intake. Nat. Neurosci. 3: 645-646.

Lee Y, Yang SP, Soares MJ and Voogt JL (2000). Distribution of prolactin-releasing peptide mRNA in the rat brain. Brain Res. Bull. 51: 171-176.

Maruyama M, Matsumoto H, Fujiwara K, Kitada C, et al. (1999). Immunocytochemical localization of prolactin-releasing peptide in the rat brain. Endocrinology 140: 2326-2333.

Morales T and Sawchenko PE (2003). Brainstem prolactin-releasing peptide neurons are sensitive to stress and lactation. Neuroscience 121: 771-778.

Nieminen ML, Nystedt J and Panula P (2003). Expression of neuropeptide FF, prolactin-releasing peptide, and the receptor UHR1/GPR10 genes during embryogenesis in the rat. Dev. Dyn. 226: 561-569.

Yamada M, Ozawa A, Ishii S, Shibusawa N, et al. (2001). Isolation and characterization of the rat prolactin-releasing peptide gene: multiple TATA boxes in the promoter region. Biochem. Biophys. Res. Commun. 281: 53-56.

Yamakawa K, Kudo K, Kanba S and Arita J (1999). Distribution of prolactin-releasing peptide-immunoreactive neurons in the rat hypothalamus. Neurosci. Lett. 267: 113-116.

Yano T, Iijima N, Kataoka Y, Hinuma S, et al. (2001). Developmental expression of prolactin releasing peptide in the rat brain: localization of messenger ribonucleic acid and immunoreactive neurons. Brain Res. Dev. Brain Res. 128: 101-111. 